\title{
Powdered Baby Formula Sold in North America: Assessing the Environmental Impact
}

\author{
Karin Cadwell, Anna Blair, Cindy Turner-Maffei, Maret Gabel, and Kajsa Brimdyr
}

\begin{abstract}
Background: According to the Intergovernmental Panel on Climate Change, Greenhouse Gas emissions must decline by around $45 \%$ by 2030 and reach net zero in 2050. Biofuels, solar, and wind energy are obvious choices for reduction of the $75 \%$ of emissions from the energy sector (including transportation), but making reductions in the remaining $25 \%$, the food sector, is more of a challenge. One way is to change our diets to increase low-carbon food alternatives.

Objective: We chose to examine the impact of powdered baby formula products. The aim of this study is to compute a minimal estimate of green house gas (GHG) emissions for powdered baby formula products sold in North America comprising Canada, Mexico, and the United States.

Results: We found that in 2016, the North America Greenhouse Gas emissions (in tons of $\mathrm{CO}_{2}$ eq.) attributable to sales of powdered formula for Canada was 70,256, for Mexico, 435,820, and for the United States, 655,956. The North American per capita emissions based on infants and toddlers from birth to 36 months of age in 2016 was, at a minimum, $59.06 \mathrm{~kg}$ of $\mathrm{CO}_{2}$ eq.

Conclusion: The environmental and Greenhouse Gas impact of powdered baby formula, and related hazards arising from climate change, can be a relevant factor for health care providers in their advice to families on infant feeding. This study makes an innovative and potentially useful addition to the emerging evidence on this issue and should be considered when developing and funding infant and young child feeding policies and supportive programs.
\end{abstract}

Keywords: infant formula, carbon footprint, global warming, breast milk substitute, breastfeeding

\section{Introduction}

$\mathbf{T}$

The Intergovernmental Panel on Climate Change (IPCC) was established in 1988 to "provide policymakers with regular scientific assessments on climate change, its implications and potential future risks, as well as to put forth adaptation and mitigation options." "1 Their October 2018 report ${ }^{2}$ warns that carbon dioxide $\left(\mathrm{CO}_{2}\right)$ emissions need to decline by around $45 \%$ by 2030 and reach net zero in 2050 . Energy (as electricity, heat, transportation, or for use in industry) accounts for about $75 \%$ of emissions. ${ }^{3}$ Improvements in energy efficiencies, low-carbon energies (solar and wind, e.g.), and renewable energies have been embraced as clean energy solutions for decreasing the emissions in this $75 \%$ portion. Food production and processing accounts for about one quarter of carbon emissions, but finding solutions in this sector are challenging, less clear, and will require a wide menu of solutions, including food waste reduction, improvements in agriculture technology, and changing diets to low-carbon food alternatives. ${ }^{4}$

The aim of this study is to compute a minimal estimate of green house gas (GHG) emissions for powdered baby formula products sold in North America comprising Canada, Mexico, and the United States.

Worldwide, the size of the market for baby formula, which can be considered as both an agricultural and a manufactured food, has been valued at more than 45 billion USD with a projection that it will be more than 103 billion USD by 2026 , a growth rate higher than the expected increase in population. The market for formula in the United States is expected to grow from more than 2.5 billion USD in 2018 to more than 5 billion USD by $2026 .^{5}$

Healthy Children Project, East Sandwich, Massachusetts, USA.

(c) Karin Cadwell et al. 2020; Published by Mary Ann Liebert, Inc. This Open Access article is distributed under the terms of the Creative Commons Attribution Noncommercial License (http://creativecommons.org/licenses/by-nc/4.0/) which permits any noncommercial use, distribution, and reproduction in any medium, provided the original author(s) and the source are credited. 
If an infant is not fed human milk, an approved commercial infant formula is the acknowledged next best choice in North America. In spite of efforts by the World Health Assembly (WHA) since the mid-1980s to encourage governments to level the playing field with regard to the marketing of formula to consumers and health care providers, only a few countries have put the WHA recommendations, known as the International Code of Marketing of Breast-Milk Substitutes and subsequent resolutions, into full effect. ${ }^{6}$ For example, the United States' formula sales were U.S. \$4.8 billion in 2013 (\$1220.69 per baby) with $10-15 \%$ of sales turned toward marketing (conservatively, $\$ 480$ million), over six times the $\$ 68$ million spent on breastfeeding by the government of the United States. ${ }^{7}$

Internationally about $60 \%$ of infants under the age of 5 months are not exclusively breastfed and so are fed breast milk substitutes (BMS) usually infant formula. ${ }^{8}$ Canada $^{9}$ and the United States ${ }^{10}$ both report slightly more than half of babies receiving any breast milk at 6 months, and Mexico reports a rate of about $30 \% .{ }^{11}$ The World Health Organization (WHO) and the United Nations Children's Fund (UNICEF), ${ }^{12}$ along with other governmental and professional agencies and organizations, recommend that, with few exceptions, babies be breastfed within the first hour of birth, be fed only human milk for about the first 6 months, and continue breastfeeding to 2 years and beyond. Nutritious, culturally appropriate foods should be added to the diet beginning at about 6 months. This recommendation is for both high- and low-resource countries. ${ }^{13}$ According to the European Food Safety Authority (EFSA), "the use of milk-based 'growing-up' formula does not bring additional value to a balanced diet in meeting the nutritional requirements of young children in the European Union ... EFSAs scientific experts could identify 'no unique role' for young-child formula (commonly called 'growing-up formula') in the diet of young children (those aged 1-3)." 14 The WHO concurs that these formulas are unnecessary and unsuitable when used as a breast milk replacement after 6 months of age. Issues include that these formulas are too high in protein while low in essential fatty acids, iron, zinc, and B vitamins when compared with WHO recommendations for adequate growth and development of infants and young children. ${ }^{15-17}$

The health reasons to support breastfeeding policies and practices have been summarized in a meta-analysis included in the 2016 Lancet Series on breastfeeding. ${ }^{18}$ A host of advantages for both mother and child, as well as the risks of not breastfeeding, were elucidated. Optimal infant and young child feeding (IYCF) could prevent 823,000 deaths per year of children under the age of 5 (with 9 out of 10 of those deaths worldwide being infants under 6 months of age). ${ }^{18}$ In addition, breastfeeding populations are more resilient in emergencies according to Smith. ${ }^{19}$

Optimal IYCF could prevent 20,000 annual deaths of women from breast cancer. ${ }^{18}$ The 2016 Lancet Series also reported that the current low rates of breastfeeding result in cognitive loss, and thus reduced earning potential, especially in high-income countries. ${ }^{20}$ An analysis targeting the cost of not breastfeeding in the United States concluded that for every 597 women who optimally breastfeed, 1 maternal or child death is prevented. ${ }^{21}$ Almost $80 \%$ of the excess costs and deaths due to suboptimal breastfeeding in the United States are maternal. ${ }^{21}$

Although wet nursing was practiced through the ages, animal milk feeding practices also have been reported. If an infant is not fed human milk, a replacement food, a BMS is offered. Four-thousand-year-old feeding implements and vessels containing remnants of animal milks have been unearthed by archeologists in the graves of young children. ${ }^{22}$ The assayed foods from the found vessels were largely unaltered animal milks, although historical records indicate that honey and wine were also fed when human milk feeding was not possible. ${ }^{23}$ As recently as the 1800 s an estimated onethird of BMS-fed children died in their first year. ${ }^{24}$

According to Stevens et al., ${ }^{25}$ beginning in 1865 scientists tried to humanize animal milks to create a synthetic formula equal to human milk. This work continues today ${ }^{26}$ and although nutritional standards have been set by the government $^{27,28}$ and the Codex Alimentarius, ${ }^{29}$ lead, cadmium, arsenic, and other inclusions in BMS products continue to raise concerns. ${ }^{30}$

Increased understanding of germ theory, implementation of more hygienic food preparation practices, and home refrigeration as well as the increasing availability of feeding implements, such as rubber nipples beginning in the late 1800s, led not only to the emergence of home-prepared BMS, but a flourishing commercial BMS industry. By the beginning of the 20th century, physicians began to recommend commercial formula in the form of both powder and "ready-to-drink" 31 now, "ready to feed" — preparations. By 1929 professional organizations became involved. According to Stevens et al., "In 1929, the American Medical Association formed the Committee on Foods to approve formula safety, forcing many baby food companies to seek AMA approval or the organization's 'Seal of Acceptance.',"25 Today, powdered formula is estimated to be at least $70 \%$ of the United States' ${ }^{32}$ and Canada's BMS market, ${ }^{33}$ and virtually $100 \%$ of the Mexican market. ${ }^{34}$ Powdered formula, like any manufactured product, produces GHG emissions and ultimately contributes to climate change by raising the planetary temperature as these emissions trap solar energy in the atmosphere.

\section{Materials and Methods}

The steps in our data collection and analysis are described in Table 1. This study used the approach pioneered in Dadhich et al. ${ }^{35}$ to compute a minimal estimate of GHG emissions for powdered baby formula products. We used retail sales data from the year 2016 in the North American countries of Canada, Mexico, and the United States provided by Euromonitor. Dadhich et al. ${ }^{35}$ reported their calculations of the GHG emissions of baby formula sold in six Asia and Pacific Region countries, India, Philippines, China, Malaysia, Australia, and South Korea. Two of these countries alone (China and India) currently account for about 2.7 billion (37\%) of the entire global population of roughly 7.7 billion, whereas North America accounts for about 5\%.

Recipes for each powdered formula as well as the amount sold at a retail level in North America in 2016, by country, were obtained from Euromonitor International. ${ }^{36}$ The amount of powdered formula sold at retail in North America, rather than the amount produced in North America, was selected as the basis for our calculations because the formula industry is globalized and it is difficult to know precisely where every product is distributed. Both Canadian and Mexican formulas originate in the United States. It is estimated that there are only $40-50$ baby milk factories in the world. ${ }^{37}$ 
Table 1. Steps in the Computation of the Carbon FoOTPRINT OF POWDER Formula SOLd IN NORTH AMERICA

\begin{tabular}{ll}
\hline Step no. & Task \\
\hline $1 . \quad$ & Retrieve industry data on powdered milk \\
formula sales in Canada, Mexico, and the \\
United States from Euromonitor \\
(Euromonitor International, 2017 ${ }^{33}$ ) \\
Retrieve the recipes for powdered formula \\
blends using the Euromonitor international \\
industry data, which include ingredients and \\
the percent of each ingredient in the finished \\
product \\
Use available published literature to calculate \\
the emission contribution of each ingredient \\
according to the percentage of its inclusion \\
Calculate the carbon emissions due to the \\
production of each of the powdered formula \\
blends \\
Compute the carbon footprint of each type of \\
powdered formula in North America by \\
country based on sales, including per capita \\
calculation of infants and young children \\
from birth to 36 months in each country and \\
the total for North America \\
Translate measurements of CO ${ }_{2}$ using the \\
Greenhouse Gas Equivalencies Calculator \\
(United States Environmental Protection \\
Agency EPA, 2015 \\
comparisons into easily understood \\
5.
\end{tabular}

$\mathrm{CO}_{2}$, carbon dioxide.

\section{Data collection}

Data on the production emissions of major recipe ingredients from "farm to gate" (meaning from the collection of raw material through the factory processing of that ingredient, but not packaging or transportation), were taken from the literature (Table 2). The industry data provided by Euromonitor International ${ }^{33}$ included the retail sales amount and the percent composition of the major ingredients for each of the classes of powdered formula sold at retail in North America. The major components of both human milk and manufactured formulas are proteins, fats, and carbohydrates. When prepared, according to the manufacturer's instructions, the amount of these components for the major brands falls within the standards set by the United States Food and Drug Administration (FDA).

The three primary types of powdered formula sold in the United States include Standard, Growing-Up, and Special formula. In Canada and Mexico there are four primary types: Standard, Follow-On, Growing-Up, and Special formula. All are produced in the United States. Standard formulas are designed to be fed to a child 0-12 months of age, Follow-On formula is for a child older than 6 months and younger than 12 months, whereas Growing-Up formula is specified for children over 12 months of age. Special formula is to be given to children to address certain conditions such as food intolerance or allergies, especially to other formulas.

Formula is a blended product, and as such, each of the types of formula has a different recipe. Standard powdered formula is the only product to contain whey powder and only the Follow-On recipe includes maltodextrin/starch. The Growing-Up blend is the only recipe that contains full cream milk powder. The unique ingredients in the Special powdered formula blend are protein hydrolysates and/or soy protein isolate as well as glucose/corn syrup. Each major ingredient for each recipe is included in our partial life cycle calculations of GHG emissions.

GHG emissions are usually expressed in carbon dioxide equivalents $\left(\mathrm{CO}_{2}\right.$ e or $\mathrm{CO}_{2}$ eq. $)$, which are thought to comprise about $80 \%$ of the total amount of GHG emitted. ${ }^{38} \mathrm{Be}-$ cause estimates of food production-associated emissions include agricultural practices, $\mathrm{CO}_{2}$, methane $\left(\mathrm{CH}_{4}\right)$, and nitrous oxide $\left(\mathrm{NO}_{2}\right)$ are included in the calculations of $\mathrm{CO}_{2}$ equivalents of most foods. The $\mathrm{CO}_{2}$ eq. values for individual ingredients are listed in Table 2 and enumerated below.

Milk powder is an ingredient in Standard, Follow-On, and Growing-Up powdered formula. Milk powder begins with raw milk. Gerber et al. ${ }^{39}$ have estimated the average

Table 2. Assumed $\mathrm{CO}_{2}$ EQ./KG Values for Individual Major Ingredients Used in Powdered Formula Sold IN NorTh AMERICA

\begin{tabular}{|c|c|c|c|c|}
\hline \multicolumn{3}{|l|}{ Ingredients } & $\mathrm{CO}_{2} / \mathrm{kg}$ & Reference \\
\hline Skimmed milk powder & & & 12.64 & Gerber et al. ${ }^{39}$ \\
\hline Whole milk powder & & & 12.7 & Gerber et al. ${ }^{39}$ \\
\hline Whey powder (dry whey) & & & 13.35 & Innovation Center for U.S. Dairy \\
\hline Protein hydrolysates & & & 30 & Boland $^{43}$ \\
\hline Lactose & & & 0.78 & Flysjö $^{45}$ \\
\hline Soy protein isolate & & & 20.2 & Berardy et al. ${ }^{42}$ \\
\hline Glucose & & & 0.949 & An et al. \\
\hline Corn syrup & & & 2.51 & Kendall et al. ${ }^{47}$ \\
\hline Starch/Maltodextrin & & & 0.877 & An et al. ${ }^{6}$ \\
\hline Vegetable oil & & & 1.62 & Munoz et al. ${ }^{51}$ \\
\hline Ingredient & Fraction, \% & Calculation & & $\begin{array}{l}\text { United States Environmental Protection } \\
\text { Agency EPA }\end{array}$ \\
\hline Palm oil & 46 & 2.02 & & \\
\hline Soybean oil & 23 & 2.02 & & \\
\hline Coconut oil & 23 & 0.76 & & \\
\hline Sunflower oil & 8 & 0.76 & & \\
\hline
\end{tabular}

$\mathrm{CO}_{2}$, carbon dioxide. 
greenhouse emissions at the farm gate to be $1.23 \mathrm{~kg} \mathrm{CO}_{2}$ eq./ $\mathrm{kg}$ milk. The production of milk powder starts with raw whole milk being cooled and stored. Next, raw milk is separated into components. The skimmed or whole milk portion is then homogenized, pasteurized, and subjected to the process of evaporation. It is then mixed, dried, cooled, and packaged as milk powder. The emissions estimate ${ }^{39}$ for the production of skimmed milk powder are $0.157 \mathrm{~kg}$ of $\mathrm{CO}_{2}$ eq. $/ \mathrm{kg}$. Adding the raw milk emissions to the powdered milk production emissions $\left(1.23+0.157=1.39 \mathrm{~kg} \mathrm{CO}_{2}\right.$ eq. $)$ yields the emissions of skimmed milk powder and $\left(1.23+0.171=1.40 \mathrm{~kg} \mathrm{CO} \mathrm{CO}_{2}\right.$ eq. $)$ for whole milk powder. According to a FAO report, ${ }^{39} 20 \mathrm{~kg}$ of milk are needed to produce $2.2 \mathrm{~kg}$ of milk powder, therefore, the final estimate we are using is $12.64 \mathrm{~kg}$ of $\mathrm{CO}_{2}$ eq. $/ \mathrm{kg}$ for skimmed milk powder and $12.7 \mathrm{~kg}$ of $\mathrm{CO}_{2}$ eq. $/ \mathrm{kg}$ for whole milk powder (Table 2).
Glucose and high fructose corn syrup can be produced through wet milling or dry milling processes. The reported emissions for glucose are $0.949 \mathrm{~kg}$ of $\mathrm{CO}_{2}$ eq. $/ \mathrm{kg}^{46}$ and for corn syrup, $2.51 \mathrm{~kg}$ of $\mathrm{CO}_{2}$ eq. $/ \mathrm{kg}$. ${ }^{47}$

Follow-On formula contains maltodextrin/starch. Data from An et al. ${ }^{46}$ report a value of $0.877 \mathrm{~kg}$ of $\mathrm{CO}_{2}$ eq. $/ \mathrm{kg}$ of starch. We could find no specific data for the production of maltodextrin, but since it is produced from starch it can be assumed that the emissions amount is at least $0.877 \mathrm{~kg}$ of $\mathrm{CO}_{2}$ eq. $/ \mathrm{kg}$.

There are four major vegetable oils combined together in North American formulas: palm, soybean, coconut, and sunflower seed. We based our proportions on the order in which the oils were listed on product labels at retail and on the listed proportions for three formulas available on formula company websites, ${ }^{48-50}$ so we assumed proportions of $46 \%$ for palm oil, 23\% each for soybean and coconut oils, and $8 \%$ for sunflower seed oil. Palm and soybean oil both have an

$$
\frac{1.39 \mathrm{~kg} \text { of } \mathrm{CO}_{2} \text { eq. }}{1 \mathrm{~kg} \text { of milk at the farm gate }} \times \frac{20 \mathrm{~kg} \text { of milk at the farm gate }}{2.2 \mathrm{~kg} \text { of milk powder }}=12.64 \mathrm{~kg} \text { of } \mathrm{CO}_{2} \text { eq. } / \mathrm{kg} \text { of skim milk powder }
$$

$$
\frac{1.40 \mathrm{~kg} \text { of } \mathrm{CO}_{2} \text { eq. }}{1 \mathrm{~kg} \text { of milk at the farm gate }} \times \frac{20 \mathrm{~kg} \text { of milk at the farm gate }}{2.2 \mathrm{~kg} \text { of milk powder }}=12.7 \mathrm{~kg} \text { of } \mathrm{CO}_{2} \mathrm{eq} . / \mathrm{kg} \text { of whole milk powder }
$$

Whey powder is a by-product of the extraction of the protein casein from milk. The published estimate of emissions for dry whey range from $12.4 \mathrm{~kg} \mathrm{CO}$ eq. $/ \mathrm{kg}^{40}$ to $14.3 .{ }^{41}$ We have averaged the two estimates and are using the value of 13.35 (Table 2).

There are three major proteins in powdered formula that are fully or partially hydrolyzed: soy, casein, and whey. The published emissions calculation for soy protein isolate is $20.2 \mathrm{~kg} \mathrm{CO}$ eq. $/ \mathrm{kg} .{ }^{42}$ Protein hydrolysates are produced by combining the protein (in the case of Special formula, whey, and soy), with proteolytic enzymes at a temperature that is usually between $37^{\circ} \mathrm{C}$ and $40^{\circ} \mathrm{C}$. According to Boland, writing in the Handbook of Food Proteins, "the mixture of enzymes used and the exact processing conditions will vary from one manufacturer to another and this is usually proprietary information." 43 Probably because of the very proprietary nature of this process, we were not able to find research studies to give us specific guidance on the environmental impact of the ingredient protein hydrolysate. However, we know it is greater than the production of the ingredient whey powder, and at least in one industry publication, twice the emissions of soy isolate. ${ }^{44}$ For the purpose of our calculations, we have chosen the conservative value of $30 \mathrm{CO}_{2} \mathrm{eq} . / \mathrm{kg}$.

Lactose is a carbohydrate found in the milk of mammals and is processed similarly to whey. Human milk has one of the highest percentages of lactose when compared with other mammals, and cow's milk has about half of that amount. Therefore, additional lactose from cow's milk is added to the formula blends to make the formulation more like human milk. According to Flysjö, ${ }^{45}$ lactose production emissions are $0.78 \mathrm{~kg}$ of $\mathrm{CO}_{2}$ eq. $/ \mathrm{kg}$ lactose. emissions impact of $2.02 \mathrm{~kg}$ of $\mathrm{CO}_{2}$ eq. $/ \mathrm{kg}$ with the value for coconut and sunflower seed oil at $0.76 \mathrm{~kg}$ of $\mathrm{CO}_{2}$ eq. $/ \mathrm{kg} .{ }^{51}$ Using the assumed proportions, the value we used for vegetable oil is $1.62 \mathrm{~kg}$ of $\mathrm{CO}_{2}$ eq. $/ \mathrm{kg}$.

\section{Results}

The calculations for the GHG emissions for each type of powdered formula in each of the three countries of North America are included in Table 3. Our partial lifecycle calculation found that standard powdered formula (according to the Euromonitor recipe and using the published ingredient estimates described in Table 2) was $8.49 \mathrm{CO}_{2}$ eq. $/ \mathrm{kg}$. Karlsson et al., ${ }^{52}$ who reported their results of a life cycle assessment of BMS from production to consumption, used as their baseline, a composition in compliance with the Codex Alimentarius standards with a Monte Carlo simulation to generate recipes. Their estimate of the carbon footprint of United States packaged BMS at the factory gate is somewhat lower at $7.1 \pm 1 \mathrm{CO}_{2}$ eq./kg compared with our estimate of 8.49 . The Karlsson et al. ${ }^{52}$ report did not include Special, Follow-On, or Growing-Up formulas in the calculations. Dadhich et al., ${ }^{35}$ on the other hand, did include all categories of baby formula products but found little difference in the $\mathrm{GHG}$ emissions of around $4 \mathrm{~kg} \mathrm{CO}$ eq. $/ \mathrm{kg}$.

We found that Special powdered formula was calculated to have the lowest amount of $\mathrm{GHG}$ emissions at $5.38 \mathrm{CO}_{2} \mathrm{eq} . / \mathrm{kg}$ due to the composition of this formulation and the percentage of soy protein isolate. In Special formula, soy protein isolate and protein hydrolysates together are only $17.1 \%$ of the total recipe at an ingredient cost of $20.2 \mathrm{CO}_{2}$ eq. $/ \mathrm{kg}$ and $30 \mathrm{CO}_{2}$ eq. $/ \mathrm{kg}$ and with an ingredient environmental cost of $3.28 \mathrm{CO}_{2}$ eq. $/ \mathrm{kg}$ of the total $5.38 \mathrm{CO}_{2}$ eq. $/ \mathrm{kg}$. 
Table 3. Percent Composition of Each Major Nutrient Ingredient IN NorTh AMERICAN POWDER Formula Blends in ORder of PERCENT COMPOSITION, Proportional $\mathrm{CO}_{2}$ EQ./KG AND Total

\begin{tabular}{|c|c|c|c|}
\hline Ingredients & $\begin{array}{c}\text { Percent } \\
\text { composition } \\
\text { from } \\
\text { Euromonitor } \\
\text { International } \\
\text { data }\end{array}$ & $\begin{array}{c}\mathrm{CO}_{2} \\
\text { eq./kg for } \\
\text { ingredient } \\
\text { (from } \\
\text { Table 2) }\end{array}$ & $\begin{array}{l}\mathrm{CO}_{2} \\
\text { eq./kg }\end{array}$ \\
\hline \multicolumn{4}{|c|}{ North American Standard Powdered Formula } \\
\hline Whey powder & 41.1 & 13.35 & 5.49 \\
\hline Vegetable oil & 25.3 & 1.62 & 0.41 \\
\hline Skimmed milk powder & 19.6 & 12.64 & 2.48 \\
\hline Lactose & 14 & 0.78 & 0.11 \\
\hline Total & & & 8.49 \\
\hline \multicolumn{4}{|c|}{ North American Growing-Up Powdered Formula } \\
\hline Skimmed milk powder & 74 & 12.64 & 9.35 \\
\hline Lactose & 14 & 0.78 & 0.11 \\
\hline Vegetable oil & 8.2 & 1.62 & 0.13 \\
\hline Full cream milk powder & 4.2 & 12.64 & 0.53 \\
\hline Total & & & 10.12 \\
\hline \multicolumn{4}{|c|}{ North American Follow-On Formula } \\
\hline Skimmed milk powder & 73.4 & 12.64 & 9.28 \\
\hline Lactose & 14.3 & 0.78 & 0.11 \\
\hline Vegetable oil & 8.2 & 1.62 & 0.13 \\
\hline Starch/Maltodextrin & 4.1 & 0.88 & 0.04 \\
\hline Total & & & 9.56 \\
\hline \multicolumn{4}{|c|}{ North American Special Powdered Formula } \\
\hline Corn syrup & 55 & 2.51 & 1.38 \\
\hline Vegetable oil & 27 & 1.62 & 0.44 \\
\hline Soy protein isolate & 16.1 & 20.2 & 3.25 \\
\hline Protein hydrolysates & 1 & 30 & 0.3 \\
\hline Lactose & 0.9 & 0.78 & 0.007 \\
\hline Total & & & 5.38 \\
\hline
\end{tabular}

$\mathrm{CO}_{2}$, carbon dioxide.

The formulations that have milk powder as a high percentage of the recipe constituents, in comparison, have a much higher environmental cost. In the Follow-On formula recipe, for example, skimmed milk powder is $73.4 \%$ of the composition at an ingredient cost of $12.64 \mathrm{CO}_{2}$ eq. $/ \mathrm{kg}$ resulting in that ingredient alone contributing $9.28 \mathrm{CO}_{2}$ eq. $/ \mathrm{kg}$ to the 9.56 total. Growing-Up powdered formula is similar, with skimmed milk powder of $74 \%$ as the total ingredient composition. The calculated cost to the environment of this one ingredient, $9.35 \mathrm{CO}_{2}$ eq. $/ \mathrm{kg}$, is most of the $10.12 \mathrm{CO}_{2}$ eq. $/$ $\mathrm{kg}$ recipe total.

The amount of 2016 sales in tons according to Euromonitor and estimated carbon emissions are listed in Table 4 with a North American total of 1,161,932 tons. The emissions of carbon dioxide equivalents for each type of formula is a product of the amount of formula and the emissions are displayed. Standard powder sold in the United States is responsible for the highest amount of emissions with 412,614 tons of $\mathrm{CO}_{2}$ eq. from 48,600 tons of formula sold. The next highest North American amount is 239,844 tons of $\mathrm{CO}_{2}$ eq. from the only 23,700 tons of Growing-Up powder sold in Mexico. The discrepancy is due to the difference in ingredients. Standard formula ingredients combine to a $\mathrm{CO}_{2}$ eq. of 8.49, where Growing-Up powder is mainly skimmed milk powder $(74 \%)$ with a $\mathrm{Co}_{2}$
TABle 4. Estimated $2016 \mathrm{CO}_{2}$ EQ. EMISSIONS FOR Powdered Formula Sold IN Three Countries of North America

\begin{tabular}{|c|c|c|c|}
\hline & $\begin{array}{c}\mathrm{kg} \mathrm{C \textrm {CO } _ { 2 }} \\
\text { eq./kg }\end{array}$ & $\begin{array}{c}\text { Volume } \\
\text { of sales } 2016 \\
\text { in tons } \\
\text { according to } \\
\text { Euromonitor } \\
\text { International }\end{array}$ & $\begin{array}{c}\text { Estimated } \\
\text { GHG } \\
\text { emissions } \\
\text { in } 2016 \\
\text { (in tons } \\
\text { of } \mathrm{CO}_{2} \text { eq.) }\end{array}$ \\
\hline \multicolumn{4}{|l|}{ United States } \\
\hline Standard powder & 8.49 & 48,600 & 412,614 \\
\hline Follow-on powder & & 0 & 0 \\
\hline Growing-up powder & 10.12 & 4,100 & 41,492 \\
\hline Special powder & 5.38 & 37,500 & 201,750 \\
\hline Total United States & & 90,200 & 655,956 \\
\hline \multicolumn{4}{|l|}{ Mexico } \\
\hline Standard powder & 8.49 & 7,000 & 59,430 \\
\hline Follow-on powder & 9.56 & 10,400 & 99,424 \\
\hline Growing-up powder & 10.12 & 23,700 & 239,844 \\
\hline Special powder & 5.38 & 6,900 & 37,122 \\
\hline Total Mexico & & 48,000 & 435,820 \\
\hline \multicolumn{4}{|l|}{ Canada } \\
\hline Standard powder & 8.49 & 3,800 & 32,262 \\
\hline Follow-on powder & 9.56 & 2,700 & 25,812 \\
\hline Growing-up powder & 10.12 & 300 & 3,036 \\
\hline Special powder & 5.38 & 1,700 & 9,146 \\
\hline Total Canada & & 8,500 & 70,256 \\
\hline Total North America & & 146,700 & $1,161,932$ \\
\hline
\end{tabular}

$\mathrm{CO}_{2}$, carbon dioxide; GHG, green house gas.

eq. of 10.12. Follow-On formula also has almost $75 \%$ of skimmed milk powder but much less in sold; none in the United States and less than half of the amount of GrowingUp formula sold in Mexico.

Not only do different formula blends have different costs to the environment but each of the three countries in North America also has a unique buying pattern, Mexico bought far more formula for older babies. Growing-Up plus Follow-On formula amounts to 34,100 tons ( $71 \%$ of the total Mexican tonnage) compared with 7,000 tons $(14.5 \%)$ of standard formula and 6,900 tons (14.5\%) of Special formula. The United States bought 48,600 tons of Standard (54\% of the total tonnage) and 37,500 tons (42\%) of Special formula with only 4,100 tons (4\%) of Growing-Up and no Follow-On formula. Canada bought 3,800 tons of standard formula ( $45 \%$ of the total tonnage), 2,700 tons of Follow-On (32\%), and 1,700 tons of Special formula (20\%), but only 300 tons of Growing-Up formula (3\%). These differences are reflected in the per capita emissions calculation found in Table 5.

\section{Discussion}

A total of 164,700 metric tons of powdered formula were sold in North America in $2016^{33}$ with a partial life cycle emissions calculation of $1,161,932$ tons of $\mathrm{CO}_{2}$ eq. We calculated the emissions per capita for each country and for the North American total with a finding that the total was $59.06 \mathrm{~kg}$ of $\mathrm{CO}_{2}$ eq. for each person, 0-3 years of age. Each country varied from the total, United States, $56.81 \mathrm{~kg}$ of $\mathrm{CO}_{2}$ eq., Mexico $62.29 \mathrm{~kg}$ of $\mathrm{CO}_{2}$ eq., and Canada $62.04 \mathrm{~kg}$ of $\mathrm{CO}_{2}$ eq. The lower emissions per capita in the United States 
Table 5. Per Capita Analysis of Carbon Emissions in 2016 from the Manufacture of Powdered Formula Sold in North America and by Country

\begin{tabular}{lccccc}
\hline & $\begin{array}{c}\text { Number of children } \\
\text { age 0-36 months in 2016 }\end{array}$ & $\begin{array}{c}\text { Sales } \\
\text { (tons) }\end{array}$ & $\begin{array}{c}\text { Sales per } \\
\text { capita }(\mathrm{kg})\end{array}$ & $\begin{array}{c}\text { Emissions } \\
\left.\text { (tons of } \mathrm{CO}_{2} \text { eq. }\right)\end{array}$ & $\begin{array}{c}\text { Emissions per capita } \\
\left.\text { (kg of CO } \mathrm{CO}_{2} \text { eq. }\right)\end{array}$ \\
\hline United States & $11,545,228$ & 90,200 & 7.81 & 655,865 & 56.81 \\
Mexico & $6,996,586$ & 48,000 & 6.86 & 435,820 & 62.29 \\
Canada & $1,132,492$ & 8,500 & 7.51 & 70.256 & 62.04 \\
North America total & $19,674,306$ & 146,700 & 7.47 & $1,161,932$ & 59.06 \\
\hline
\end{tabular}

Sales data from Euromonitor International.

$\mathrm{CO}_{2}$, carbon dioxide.

reflects the high percentage of Special formula and the low percent of Follow-On (0\%) and Growing-Up (4\%). On the other hand, Mexico's $62.29 \mathrm{~kg}$ of $\mathrm{CO}_{2}$ eq. reflects the $71 \%$ Follow-On and Growing-Up powders sold.

To this end, we calculated the $\mathrm{CO}_{2}$ eq. emissions of the amount of powdered formula sold at retail in North America for 1 year and found it to be a substantial contributor to GHG emissions. It would take more than 1.3 million acres (over 550,000 hectares) of forests 1 year to sequester the production of the quantity of carbon dioxide emitted by the powdered formula sold at retail in North America in $2016 .^{38}$

Our findings show that, at a minimum, the $\mathrm{CO}_{2}$ emissions attributable to the powdered formula sold calculated in passenger vehicle miles equivalency for Canada was 171,775,061, in Mexico 1,065,574,572, and in the United States 1,603,581,907. The total for North America was 2,840,909,535 passenger vehicle miles or more than 114,000 times around the equator of the earth.

We used the approach and methodologies described by Dadhich et al. ${ }^{35}$ who reported their findings of the carbon footprint of formula sold in six Asian and Pacific Region countries: two high-income, two upper-middle-income, and two lower-middle-income nations. This study found GHG emissions of 2.89 million tons $\mathrm{CO}_{2}$ annually due to milk formula in the six countries. Using the U.S. Environmental Protection Agency Greenhouse Gas equivalencies calculator, it was estimated that this was equivalent to annual GHG emissions from 6.9 billion miles driven in a car. They concluded that formula is "emerging as an important source" of emissions and "relevant to on-going global efforts to address climate change and reduce carbon emissions." 35 A recent U.K. report, which used the Karlsson et al. ${ }^{52}$ data for the U.K. estimated that "breastfeeding for 6 months saves an estimated $95-153 \mathrm{~kg} \mathrm{CO}_{2}$ equivalent per baby....equating to taking 50,000 to 77,500 cars off the road each year." 37 For North America, powdered baby formula $\mathrm{Co}_{2}$ eq. GHG equates to taking 212,812 cars off the road each year. ${ }^{38}$

The average per capita sales in the six Asian and Pacific Region countries for children 0-3 years of age reported by Dadhich et al. ${ }^{35}$ was $5.39 \mathrm{~kg}$. The average of the three countries of North America was higher, at 7.47 perhaps due to the lower per capita lower breastfeeding initiation and continuation rates. So it follows that the per capita emissions are also higher, averaging $59.06 \mathrm{~kg} \mathrm{CO}_{2}$ compared with $21.66 \mathrm{~kg} \mathrm{CO} \mathrm{CO}_{2}$ average in the Asian and Pacific Region countries' calculations. Each of the Asian and Pacific Region countries has a unique buying pattern with Australia buying $41.7 \%$ as toddler and Follow-On formula, which is similar in composition to North American Growing-Up or Follow-On formula, China $73.9 \%$, India $58.5 \%$, Malaysia $83.1 \%$, the
Philippines $71 \%$, and South Korea $47.4 \%$ of its formula as toddler milk. In North America, only Mexico buys a larger amount of toddler formula, $71 \%$ is Growing-Up or FollowOn. It follows then that the national per capita emissions would vary widely according to the percentage of toddler formulas since they have the highest percentage of milk product with Malaysia calculated to have $130 \mathrm{CO}_{2} \mathrm{eq} . / \mathrm{kg}$ and Mexico the highest in North America with $62.29 \mathrm{CO}_{2}$ eq. $/ \mathrm{kg}$.

Although this work has examined the major components in powdered formula, it is not comparable by ingredient to human milk, which is species specific and contains, in addition to proteins, fats, and carbohydrates, bioactive ingredients such as antibodies, immunoglobulins, enzymes, mucins, and stem cells. In addition, the composition of human milk changes over time. For example, the milk of those who give birth prematurely is different in composition compared with those mothers who give birth at term. At 2 days after the baby's birth, human milk does not have the same composition as the same mother's milk at 2 weeks or a year later. The amount of fat in a feeding is determined by the speed of milk removal, milk volume, and the time of day or night in a diurnal fashion. ${ }^{53-55}$ In addition, human milk assumes the flavors of the mother's diet, readying the baby for family foods, ${ }^{56}$ with less conflict at mealtime. ${ }^{57}$

\section{Limitations}

This study was limited in that only the common types of powdered formula, namely, Standard infant formula, FollowOn, Growing-Up formula, and Special formula were considered. The emissions data used for formula ingredients were limited to that which was publicly available and some of the data we used may be dependent on local production and manufacturing techniques such as the size of the operation and efficiency of the process.

Another limitation may be that our calculations were based on the amount of powdered formula sold at retail, not wholesale sales or free supplies to health facilities. In addition, we did not include estimates of the emissions of liquid formulas in this calculation, estimated to be less than a quarter of the sales in the United States and Canada. Liquids are not sold in Mexico according to Euromonitor, but future research for the United States and Canada could include liquid formulas.

We did not compare the $\mathrm{CO}_{2}$ emissions of powdered formula to breastfeeding as did Karlsson et al. who calculated the environmental costs of BMS minus additional food (300$500 \mathrm{Kcal} /$ day) that the lactating woman should eat. ${ }^{52} \mathrm{Al}-$ though the addition of 300-500 Kcal/day to the diet during lactation is often recommended in the United States and 
Canada, the requirement of additional calories to make more or better milk may be inaccurate; "both the quantitative and caloric value of breast milk does not change with dieting and exercise." 58 It could be argued, however, that in the United States, the only high resource country without guaranteed and paid maternity leave, the cost of breastfeeding should include breast pumps and the storage of breast milk.

Our estimates are of only a partial life cycle of the product. Not included in the calculations were postproduction emissions such as transport of the product to retail and onward to the customer, container production, filling, and degradation, etc. or home preparation (heating water and sterilizing equipment) or disposal of associated waste. These calculations could be included in future research about the North American emissions. A 2009 article estimated that in the United States 550 million cans and 86,000 tons of metal along with 364,000 tons of paper related to formula was sent to landfills. ${ }^{59}$ Therefore, the estimates we have put forward represent a low calculation of the total environmental costs of formula use in North America.

\section{Conclusions}

As the risks of climate change become increasingly urgent, calculating the emissions of greenhouse gases in every sector of human life is essential so that pragmatic emission reduction targets can be set and progress measured. If we are to meet IPCC goal of decreasing GHG emissions by around $45 \%$ by 2030 and reach net zero in 2050, changes must be made in both the energy and the food sectors. We chose to look to the impact of powdered baby formula products. We applied the published cost to the environment of each major recipe ingredient to compute a minimal estimate of the GHG emissions for each of the countries of Canada, Mexico, and the United States as well as a total for North America. We found that in 2016, the $\mathrm{GHG}$ emissions (in tons of $\mathrm{CO}_{2}$ eq.) attributable to sales of powdered formula in North America for each infant and toddler from birth to 36 months of age in 2016 was, at a minimum, $59.06 \mathrm{~kg}$ of $\mathrm{CO}_{2}$ eq. with an annual total of 1,161,932 tons of $\mathrm{CO}_{2}$ eq.

The environmental and GHG impact of powdered baby formula products, and related hazards arising from climate change, can be a relevant factor for health care providers in their advice to families on IYCF. This study makes an innovative and potentially useful addition to the emerging evidence on this issue and should be considered when developing and funding IYCF policies and supportive programs.

\section{Disclosure Statement}

The authors declare that no competing financial interest exists.

\section{Funding Information}

No specific funding was obtained for this research.

\section{References}

1. IPCC. IPCC-Intergovernmental Panel on Climate Change. Available at https://www.ipcc.ch (accessed April 6, 2020).

2. Intergovernmental Panel on Climate Change. Global Warming of $1.5^{\circ} \mathrm{C}$. Intergovernmental Panel on Climate Change.
2018. Available at www.ipcc.ch/report/sr15 (accessed January 25, 2019).

3. IPCC. Climate Change 2014: Synthesis Report. Contribution of Working Groups I, II and III to the Fifth Assessment Report of the Intergovernmental Panel on Climate Change. IPCC. 2014:151. Available at https://epic.awi.de/id/eprint/37530/1/ IPCC_AR5_SYR_Final.pdf (accessed July 17, 2020).

4. Ritchie H. Food production is responsible for one-quarter of the world's greenhouse gas emissions. Our World in Data. Published November 6, 2019. Available at https://ourworld indata.org/food-ghg-emissions (accessed April 6, 2020).

5. Fortune Business Insights. Infant Formula Market Size, Growth \& Trends Forecast 2026. Fortune Business Insights Pvt. Ltd. 2019. Available at https://www.fortunebusiness insights.com/industry-reports/infant-formula-market-101498 (accessed January 23, 2020).

6. World Health Organization. UNICEF, International Baby Food Action Network. Marketing of Breast-Milk Substitutes: National Implementation of the International Code, Report 2018. Published online 2018.

7. Stuebe A. It's time to disarm the formula industry. Breastfeeding Medicine. Published May 20, 2016. Available at https://bfmed.wordpress.com/2016/05/20/its-timeto-disarm-the-formula-industry (accessed January 25, 2019).

8. UNICEF, WHO, Global Breastfeeding Collective. Global Breastfeeding Scorecard, 2018: Enabling women to breastfeeding through better policies and programmes. Published online July 2018. Available at https://www.who.int/ nutrition/publications/infantfeeding/global-bf-scorecard-2018 .pdf?ua=1 (accessed July 17, 2020).

9. Public Health Agency of Canada. Breastfeeding in Canada. Public Health Agency of Canada. 2018. Available at http:// publications.gc.ca/collections/collection_2018/aspc-phac/ HP15-43-2018-eng.pdf (accessed October 15, 2019).

10. Centers for Disease Control and Prevention. 2018 Breastfeeding Report Card. Centers for Disease Control and Prevention. Published August 20, 2018. Available at https:// www.cdc.gov/breastfeeding/data/reportcard.htm (accessed February 26, 2019).

11. UNICEF. Mexico (MEX)-Demographics, Health \& Infant Mortality. UNICEF DATA. Published December 2018. Available at https://data.unicef.org/country/mex (accessed October 15, 2019).

12. WHO, UNICEF. WHO | Increasing commitment to breastfeeding through funding and improved policies and programmes: Global breastfeeding scorecard 2019. Published online 2019. Available at https://apps.who.int/iris/ bitstream/handle/10665/326049/WHO-NMH-NHD-19.22eng.pdf?ua=1 (accessed January 6, 2020).

13. Kramer MS, Kakuma R. Optimal duration of exclusive breastfeeding. Cochrane Database Syst Rev 2012; CD003517. DOI: 10.1002/14651858.CD003517.pub2.

14. European Food Safety Authority. 'Growing-up' formula: No additional value to a balanced diet, says EFSA. European Food Safety Authority. Published October 25, 2013. Available at www.efsa.europa.eu/en/press/news/131025 (accessed April 6, 2020).

15. World Health Organization. Information concerning the use and marketing of follow-up formula. Published online July 17, 2013. Available at https://www.who.int/nutrition/ topics/WHO_brief_fufandcode_post_17July.pdf (accessed July 17, 2020).

16. World Health Organization. Maternal, Infant and Young Child Nutrition. Guidance on Ending the Inappropriate 
Promotion of Foods for Infants and Young Children. World Health Organization. 2016. Available at https:// apps.who.int/gb/ebwha/pdf_files/WHA69/A69_7Add1-en .pdf?ua $=1$ (accessed July 17, 2020).

17. World Health Organization. Information Note: Clarification on the classification of follow-up formulas for children 6-36 months as breastmilk substitutes. WHO/NMH/NHD/18.11. Published online 2018. Available at https://apps.who.int/iris/ bitstream/handle/10665/275875/WHO-NMH-NHD-18.11eng.pdf?ua=1 (accessed July 17, 2020).

18. Victora CG, Bahl R, Barros AJD, et al. Breastfeeding in the 21st century: Epidemiology, mechanisms, and lifelong effect. Lancet 2016;387:475-490.

19. Smith JP. A commentary on the carbon footprint of milk formula: harms to planetary health and policy implications. Int Breastfeed J 2019;14:49.

20. Rollins NC, Bhandari N, Hajeebhoy N, et al. Why invest, and what it will take to improve breastfeeding practices? Lancet 2016;387:491-504.

21. Bartick MC, Schwarz EB, Green BD, et al. Suboptimal breastfeeding in the United States: Maternal and pediatric health outcomes and costs. Matern Child Nutr 2017;13: e12366.

22. Wickes IG. A history of infant feeding. II. Seventeenth and eighteenth centuries. Arch Dis Child 1953;28:232-240.

23. Fomon S. Infant feeding in the 20th century: Formula and beikost. J Nutr 2001;131:409S-420S.

24. Weinberg F. Infant feeding through the ages. Can Fam Physician 1993;39:2016-2020.

25. Stevens EE, Patrick TE, Pickler R. A history of infant feeding. J Perinat Educ 2009;18:32-39.

26. Best Baby Formula That Is Closest To Breast Milk. All About a Healthy Baby and its Mom. Published November 15, 2018. Available at https://www.healthybabyhappyearth .com/baby-formula-closest-to-breast-milk (accessed October 15, 2019).

27. FDA, Nutrition $\mathrm{C}$ for FS and A. Infant Formula Guidance Documents \& Regulatory Information. FDA. Published August 14, 2019. Available at www.fda.gov/food/guidancedocuments-regulatory-information-topic-food-and-dietarysupplements/infant-formula-guidance-documents-regulatory-in formation (accessed October 15, 2019).

28. Health Canada. Good Manufacturing Practices (GMPs) for Infant Formula. aem. Published October 16, 2006. Available at https://www.canada.ca/en/health-canada/services/ food-nutrition/legislation-guidelines/codes-practice/goodmanufacturing-practices-infant-formula-2006.html (Accessed October 15, 2019).

29. Food and Agriculture Organization of the United Nations, World Health Organization. Codex Alimentarius: International Food Standards | Standard for Infant Formula and Formulas for Special Medical Purposes Intended for Infants. CODEX STAN 72-1981. Published online Rev. 2007 1981. Available at www.fao.org/input/download/standards/ 288/CXS_072e_2015.pdf (accessed July 17, 2020).

30. Clean Label Project. Clean Label Project Baby Food Study: Are All Baby Foods Created Equal? Published 2017. Available at https://cdn1.cleanlabelproject.org/app/uploads/ 20171101191214/baby-food-infographic1.jpg (accessed October 15, 2019).

31. Castilho SD, Barros Filho AA. The history of infant nutrition. J Pediatr (Rio J) 2010;86:179-188.

32. Oliveira V, Frazão E, Smallwood D. The Infant Formula Market: Consequences of a Change in the WIC Contract
Brand. U.S. Department of Agriculture, Economic Research Service. 2011:44. Available at https://www.ers .usda.gov/webdocs/publications/44900/6918_err124.pdf? $\mathrm{v}=0$

33. Euromonitor International. Baby Formula Products by Ingredient. Published 2017. Available at www.euromonitor .com

34. Agriculture and Agri-Food Canada. Sector Trend Analysis-Baby food in Mexico-Agriculture and AgriFood Canada (AAFC). Published June 2018. Available at www.agr.gc.ca/eng/industry-markets-and-trade/internationalagri-food-market-intelligence/reports/sector-trend-analy sis-baby-food-in-mexico/?id=1528459672486 (accessed October 15, 2019).

35. Dadhich JP, Smith J, Iellamo A, et al. Report on Carbon Footprints Due to Milk Formula: A Study from Selected Countries of the Asia-Pacific Region. BPNI/IBFAN Asia. 2015:52. Available at https://ibfanasia.org/docs/CarbonFootprints-Due-to-Milk-Formula.pdf (accessed September 18, 2018).

36. Euromonitor. Global Baby Food Overview: Key Categories, Countries and Trends | Market Research Report | Euromonitor. Available at https://www.euromonitor.com/ global-baby-food-overview-key-categories-countries-andtrends/report (accessed April 6, 2020).

37. Joffe N, Webster F, Shenker N. Support for breastfeeding is an environmental imperative. BMJ 2019;367:15646.

38. United States Environmental Protection Agency EPA. Greenhouse Gas Equivalencies Calculator. US EPA. Published August 28, 2015. Available at https://www.epa.gov/ energy/greenhouse-gas-equivalencies-calculator (accessed September 19, 2018).

39. Gerber P, Vellinga T, Opio C, et al. Greenhouse Gas Emissions from the Diary Sector: A Life Cycle Assessment. Published online 2010. Available at https://pdfs .semanticscholar.org/fa5a/de86bdea4379ea4102116aad80 2fe60d7fc7.pdf (accessed July 17, 2020).

40. Thoma G, Popp J, Shonnard D, et al. Regional analysis of greenhouse gas emissions from USA dairy farms: A cradle to farm-gate assessment of the American dairy industry circa 2008. Int Dairy J 2013;31:S29-S40.

41. Aguirre-Villegas H, Kraatz S, Milani F, et al. Sustainable Cheese Production: Understand the Carbon Footprint of Cheese. University of Wisconsin-Extension, Cooperative Extension. 2011:28.

42. ISSST, Proc.; Berardy A, Costello C, Seager T. Life Cycle Assessment of Soy Protein Isolate. Figshare Journal contribution. 2015. https://doi.org/10.6084/m9.figshare.1517821.v1

43. Boland M. 3-Whey proteins. In: Handbook of Food Proteins. Woodhead Publishing Series in Food Science, Technology and Nutrition, Phillips GO, eds. Williams, PA: Woodhead Publishing, 2011, pp. 30-55.

44. Daoust J. Is Soylent truly "Green"? Soylent Blog. Published 2019. Available at https://soylent.com/blogs/news/issoylent-truly-green (accessed October 15, 2019).

45. Flysjö A. Greenhouse Gas Emissions in Milk and Dairy Product Chains: Improving the Carbon Footprint of Dairy Products. PhD Dissertation AARHUS University, Denmark. 2012. https://www.osti.gov/etdeweb/biblio/ 22000600

46. An V, Evelien D, Katrien B. Life Cycle Assessment study of starch products for the European Starch Industry Association (AAF): Sector study. Published online 2012. Available at www.starch.eu/wp-content/uploads/2012/09/ 
2012-08-Eco-profile-of-starch-products-summary-report.pdf (accessed September 19, 2018).

47. Kendall A, Yuan J, Brodt S, et al. Carbon Footprint of U.S. Honey Production and Packing. Davis, CA: University of California, Davis, 2011, p. 23.

48. Enfamil.com. Enfamil Products Infant. Enfamil US. Available at https://www.enfamil.com/products/infant (Accessed September 19, 2018).

49. GerberGoodStart.com. Gerber ${ }^{\circledR}$ Good Start ${ }^{\circledR}$ Baby Formulas. Available at https://www.gerbergoodstart.com (accessed September 19, 2018).

50. Similac.com. Similac ${ }^{\circledR}$ Baby Formula | Nutrition for Growth \& Development. similac.com. Available at https://similac .com/baby-formula (accessed September 19, 2018).

51. Munoz I, Schmidt JH, Dalgaard R. Comparative life cycle assessment of five different vegetable oils. 2014. Available at https://lca-net.com/publications/show/comparative-lifecycle-assessment-five-different-vegetable-oils (accessed September 19, 2018).

52. Karlsson JO, Garnett T, Rollins NC, et al. The carbon footprint of breastmilk substitutes in comparison with breastfeeding. J Clean Prod 2019;222:436-445.

53. Brown KH, Black RE, Robertson AD, et al. Clinical and field studies of human lactation: Methodological considerations. Am J Clin Nutr 1982;35:745-756.
54. Cregan MD, Hartmann PE. Computerized breast measurement from conception to weaning: Clinical implications. J Hum Lact 1999;15:89-96.

55. Kent JC, Mitoulas LR, Cregan MD, et al. Volume and frequency of breastfeedings and fat content of breast milk throughout the day. Pediatrics 2006;117:e387-e395.

56. Mennella JA. Ontogeny of taste preferences: Basic biology and implications for health. Am J Clin Nutr 2014;99:704S-711S.

57. Farrow C, Blissett J. Breast-feeding, maternal feeding practices and mealtime negativity at one year. Appetite 2006;46:49-56.

58. Kominiarek MA, Rajan P. Nutrition recommendations in pregnancy and lactation. Med Clin North Am 2016;100: 1199-1215.

59. Coutsoudis A, Coovadia HM, King J. The breastmilk brand: Promotion of child survival in the face of formulamilk marketing. Lancet 2009;374:423-425.

Address correspondence to: Karin Cadwell, PhD Healthy Children Project 327 Quaker Meeting House Road East Sandwich, MA 02537

USA

E-mail: karin@centerforbreastfeeding.org 